УдК : $327.83+327.3$

\title{
НОВИЙ СВІТОВИЙ ПОРЯДОК: МІЖНАРОДНИЙ ДИСКУРС
}

Надіслано:

10.10 .2020

\section{Міщенко Алла Борисівна}

кандидат політичних наук, доцент

Київський національний університет культури і мистецтв, м. Київ, Україна

ORCID: 0000-0001-6693-6221

mishenko.ab@gmail.com
Рецензовано:

Прийнято:

06.11 .2020
20.10 .2020

Під тиском нових викликів та загроз системно змінюється і природа взаємодії між акторами міжнародних відносин. За допомогою методів системного аналізу та порівняння у статті розкриваються основні теоретичні підходи до розуміння явища «нового світового порядку», який кристалізується в результаті всеохопної глобалізації, узагальнюються сучасні тренди формування міжнародної реальності XXI століття, враховуючи нових акторів, їх вплив на стабільність та змінюваність владних систем, а також детально аналізуються концепції сучасних вчених, які формують міжнародний дискурс щодо пошуку нової парадигми світового порядку. У дослідженні визначено основні характеристики світового порядку - легітимність, механізм внесення змін і баланс сил. Визначено ключові недоліки поствоєнного світового порядку, до яких можна віднести недостатню ефективність міжнародних організацій різного рівня щодо забезпечення принципу суверенітету для держав, поваги до кордонів; дисбаланс економічного зростання між націями; відсутність дієвих санкцій щодо порушників міжнародного права й забезпечення універсальних прав громадян; дискредитована демократична політична модель, що була визнана домінантною в постбіполярну епоху тощо. Відповідно, було розглянуто сучасні підходи до формування «нового світового порядку», у результаті чого запропоновано враховувати нові реалії взаємозалежності, які визначають майбутнє мирне співжиття націй - це баланс між свободою дій національних суб’єктів та міжнародним правом; баланс між легітимністю і силою; баланс між «регіональним порядком» та «міжнародним». Загалом, міжнародний дискурс щодо пошуку меж «нового світового порядку» спільний в питаннях будівництва багатополярного світу у XXI столітті, важливості консенсусу між націями та забезпечення легітимності нових правил для усіх акторів міжнародних відносин. 
Ключові слова: актори міжнародних відносин; багатополярність; баланс сил; демократія; легітимність; світовий порядок; суверенітет; суверенні зобов'язання.

Mishchenko Alla, Ph. D. in Political Science, Associate Professor, Kyiv National University of Culture and Arts, Kyiv, Ukraine

\section{New World Order: International Discourse}

The nature of cooperation regularly changes under pressure from new calls and threats between the actors of international relations. By means of system analysis and comparison methods, the article discloses the basic theoretical approaches to understanding of the "new world order" phenomenon, which as a result turns into a comprehensive globalization. The article summarizes the modern trends of forming the XXI century international reality, taking into account new actors, their influence on stability and variability of the imperious systems, and analyzes in detail the concepts of modern scientists who form an international discourse on the search for a new paradigm of world order. The study identifies the main characteristics of the world order - legitimacy, the mechanism of change and balance of power. The key shortcomings of the post-war world order have been identified, which include the lack of effectiveness of international organizations at various levels in ensuring the principle of sovereignty for states, respect for borders; imbalance of economic growth between nations; lack of effective sanctions against violators of international law and ensuring the universal rights of citizens; discredited democratic political model, which was recognized as dominant in the post-bipolar era, and so on. Accordingly, there were considered modern approaches to a "new world order" formation, as a result of which it was proposed to take into account the new realities of interdependence that determine the future peaceful coexistence of nations - a balance between freedom of national actors action and international law; balance between legitimacy and power; balance between "regional order" and "international". In general, the international discourse on the search for the "new world order" boundaries is common in the construction of the XXI century multipolar world, the importance of consensus between nations and the legitimacy of new rules for all actors in international relations.

Key words: actors of international relations; multipolarity; balance of power; democracy; legitimacy; world order, sovereignty; sovereign obligations.

Мищенко Алла Борисовна, кандидат политических наук, доцент, Киевский национальный университет культуры и искусств, г. Киев, Украина

\section{Новый мировой порядок: международный дискурс}

Под давлением новых вызовов и угроз системно меняется и природа взаимодействия между акторами международных отношений. С помощью 
методов системного анализа и сравнения в статье раскрываются основные теоретические подходы к пониманию явления «нового мирового порядка», который кристаллизуется в результате всеобъемлющей глобализации, обобщаются современные тренды формирования международной реальности XXI века, учитывая новых актеров, их влияние на стабильность и сменяемость властных систем, а также подробно анализируются концепции современных ученых, которые формируют международный дискурс по поиску новой парадигмы мирового порядка. В исследовании определены основные характеристики мирового порядка - легитимность, механизм внесения изменений и баланс сил. Определены ключевые недостатки поствоенного мирового порядка, к которым можно отнести недостаточную эффективность международных организаций различного уровня по обеспечению принципа суверенитета государств, уважения к границам; дисбаланс экономического роста между нациями; отсутствие действенных санкций в отношении нарушителей международного права и обеспечения универсальных прав граждан; дискредитирована демократическая политическая модель, которая была признана доминирующей в постбиполярной эпохе и т. п. Соответственно, были рассмотрены современные подходы к формированию «нового мирового порядка», как следствие предложено учитывать новые реалии взаимозависимости, которые определяют будущее мирное сожительство наций - это баланс между свободой действий национальных субъектов и международным правом; баланс между легитимностью и силой; баланс между «региональным порядком» и «международным». В целом, международный дискурс по поиску границ «нового мирового порядка» общий в вопросах строительства многополярного мира в XXI веке, важности консенсуса между нациями и обеспечения легитимности новых правил для всех актеров международных отношений.

Ключевые слова: актеры международных отношений; многополярность; баланс сил; демократия; легитимность; мировой порядок; суверенитет; суверенные обязательства.

\section{Вступ}

Міжнародна система, яка була сформована після розпаду Радянського Союзу зазнавала якісних змін та удосконалень, балансуючи між різноманітними інтересами нових гравців і центрів впливу. Єдиного та загальновизнаного джерела поведінки та сприйняття реальності не існувало з періоду завершення холодної війни. Усі спроби окреслити єдине бачення розвитку світу, міждержавних взаємодій та ролі недержавних інституцій набували рекомендаційного характеру, що дозволяло втручатися, змінювати, руйнувати, а інколи й удосконалювати існуючі правила поведінки різноманітних акторів. 
Відповідно, у 2020 році, коли світ поглинули неконтрольовані процеси поширення пандемії, наростання економічної рецесії, прихід до влади популістичних політичних еліт, руйнація довіри до ключових бюрократичних інститутів влади, поширення ядерної зброї та посягання на суверенітет незалежних державних утворень, міжнародні відносини набувають нових ознак гібридного розвитку й квазілегітимності.

\section{Аналіз останніх досліджень і публікацій}

Найбільш відомі системні дослідження світового порядку з урахуванням широкого спектру критеріїв соціально-політичного, військового, економічного та міжнародного були здійсненні такими вченими: Г. Веллсом «Новий світовий порядок» (1940), З. Бжезинським «Велика шахівниця» (1993), Д. Найемом «Який новий світовий порядок?» (1994), Е. Тоффлером «Нова парадигма влади» (2003), Т. Л. Фрідманом «Світ плаский» (2008), Г. Кіссінджером «Світовий порядок. Роздуми про характер націй в історичному контексті» (2017), Р. Хаасом «Розхитаний світ. Зовнішня політика Америки і криза старого ладу» (2019), В. Горбуліним «Світова гібридна війна. Український фронт» (2017), М. Наїмом «Занепад влади» (2018), Д. Кулебою «Війна за реальність» (2019), Л. Кай-Фуомом «AI. Наддержави штучного інтелекту. Китай, Кремнієва долина і новий світовий лад» (2020) тощо.

Варто виділити комплексні дослідження проблеми становлення нового світопорядку та його впливу на Україну й серед вітчизняних вчених: О. Дашевська «Новий світовий порядок: теоретичні концепції» (2015), Н. Зарицька «Економічне співробітництво України та США у форматі нового світопорядку» (2016), В. Зубов «Новий світовий порядок: кроскультурний пастиш» (2016), О. Коппель, З. Кісільова «Новий міжнародний порядок: структурні характеристики та особливості формування» (2009), О. Матвєєва «Трансформація світового порядку в умовах глобальних загроз і викликів» (2016), В.Романова «Світовий порядок і глобальне управління» (2011), О. Семотюк «Новий світовий порядок - моделі, антимоделі, сценарії» (2000), М. Фесенко «Концептуальна інтерпретацій міжнародного та світового порядку» (2014), В. Фісанов «Світовий порядок “доби” Барака Обами і Дональда Трампа: еволюція поглядів і рішень» (2017), М. Ялі «Формування нового світового порядку в умовах глобалізації» (2007) і т. д.

Також значну увагу висвітленню пошуку ключових характеристик і тенденцій нового світового порядку в різні історичні періоди поствоєнного розвитку міжнародної системи приділяли автори-публіцисти та політики найвищого рівня, які часто робили дану тему більш популярною, конспірологічною та футуристичною, а тому й надзвичайно актуальною. 


\section{Виділення не вирішених раніше частин загальної проблеми}

Стаття присвячена розкриттю не лише ключових теоретичних підходів до розуміння явища «нового світового порядку», а й виокремленню сучасних трендів формування міжнародної реальності XXI ст., враховуючи нових акторів, їх вплив на стабільність та змінюваність владних систем, 3 метою врахувати головні виклики та загрози для окремих націй та глобального світу загалом.

\section{Формулювання цілей статті}

Систематизувати підходи до розуміння та змістовного наповнення явища «нового світового порядку»; виокремити ключові характеристики світового порядку; розкрити особливості міжнародного дискурсу щодо формування нової парадигми «світового порядку» через визначення ключових викликів та загроз як для суверенних держав, так і неурядових суб'єктів.

Для реалізації поставлених завдань було використано системний i порівняльний метод, які забезпечили комплексне обгрунтування явища, виокремлення його структурних елементів та екстраполяції в майбутні стани, враховуючи історичні аналогії та різноманітні підходи щодо його видозміни.

\section{Виклад основного матеріалу дослідження}

2020 рік ознаменувався не лише початком світової пандемії (Covid-19), а й виразною кризою міждержавного співробітництва щодо вироблення й дотримання спільних типів поведінки на основі сформованих правил, збереження встановленої вертикалі влади, авторитету наддержавних організацій та структур неурядового походження.

Такі міжнародні організації як ООН, В003, СОТ зазнали нищівної критики через відсутність адекватних і швидких дій щодо зупинення поширення пандемії та вироблення загальних підходів щодо протоколів лікування хворих, порятунку національних економік. Тут також варто зазначити про застосування державам протекціоністських заходів, що часто не збігаються із взятими ними зобов'язаннями перед фінансово-економічними організаціями (СОТ, МВФ, СБ тощо), але вимушеними йти на такі кроки в результаті зниження темпів економічного зростання. Такі дії доводять зміну тренду - від прагнення приєднання до міжнародних організацій вкінці 2000-х на ігнорування й порушення правил членства задля національних інтересів.

Також критичним залишається розбіжність світової спільноти в питанні забезпечення миру. Кількість локальних конфліктів, у які задіянні в тому числі наймогутніші держави світу щороку зростає, але найбільше занепокоєння викликає збільшення конфліктів на політичному підгрунті (World Humanitarian Data and Trends, 2017), про що свідчать дані 00Н. Відповідно, це наштовхує на думку, що міжнародні організації та різноманітні системи колективної безпеки, що були сформовані за ініціативною найбільш впливових гравців, зменшили свою ефективність й не здійснюють свого прямого призначення - 
бути «щитом» чи «парасолькою» для ключових учасників об’єднання у випадку нападу іншого актора міжнародних відносин.

В. Горбулін зазначає, що «ми спостерігаємо певний масштабний реверсивний процес: цивілізований світ, вийшовши у XXI ст. 3 величезними планами на мирний і благополучний розвиток, зіштовхнувся з реваншистською Росією, яка спочатку стрімко відкинула нас назад, у 80-ті роки, а тепер готується й далі повертати історію назад» (Horbulin, 2017).

Виходячи з вищесказаного, можна сформулювати ще одну ключову тенденцію, яка народжується в такій нестабільній системі, але є критично важливою для збереження стабільності в світі, - це дискредитація міжнародного права як джерела універсальності та справедливості по відношенню до будьякого громадянина, етносу, нації, держави та груп держав.

Окремо слід згадати про системні нападки на демократію й їі ключові принципи, 3 якими ніби крокує формування «нового світового порядку». Якщо після розпаду СРСР ніхто не ставив питання про перемогу капіталізму над соціалізмом, а вся пропагандистська машина західного світу однозначно зафіксувала «останній хресний хід» демократії до «інакодумців» (Ф. Фукуяма, С. Хантігтон, 3. Бжезинський), то події 11 вересня 2001 року - напад на баштиблизнюки в США - ознаменував перегляд світової політики й доцільності одностороннього поширення демократії. Значна кількість країн ісламського світу, пострадянського простору у процесі власної трансформації виявилися не здатними до швидких і системних змін, що й породило суттєві сумніви як на рівні політичної еліти, так і суспільства загалом щодо доцільності такої системи. Саме тому є важливим сформувати ключові підходи до розуміння явища «нового світового порядку» та окреслити його особливості після 2020 року.

Якщо згадати першу спробу описати це поняття, то варто розпочати із праці відомого англійського дослідника Г. Веллса. Він зазначав, що новий світовий порядок (після 1940 років) має грунтуватися на трьох базових принципах: соціалізмі, законі, знаннях. Для автора було важливо підкреслити, що світ має бути побудований на повному світовому соціалізмі, науково спланованому й керованому, а крім цього критично важливим має стати неухильне й жорстке дотримання законів, повага до прав людини, свобода слова, друку, критики тощо. Такий собі спосіб примирити монархію і республіку, капіталізм і соціалізм, демократію і комунізм.

Частково такий підхід можна знайти у обгрунтованій у 50-60 pp. XX ст. теорії конвергенції, яку просували такі вчені як П. Сорокін, Дж. Гелбрейт, У. Ростоу, Х. Шельський та О. Флейтхейм, Я. Тінберген, прихильниками також були А. Сахаров і З. Бжезинський. 
Вдалим можна вважати визначення «світовий порядок», який О. Коппель i 3. Кісільова пропонують розглядати як «ідентифіковану за часом, в фізичному та міжнародно-політичному просторі структуру взаємозв'язків, заснованих на системі норм і правил, вироблених світовим співтовариством, які регулюють відносини держав та інших суб'єктів міжнародної системи на певному історичному етапі розвитку, а також на різних ієрархічних рівнях цієї системи, які відповідають потребам найвпливовіших суб'єктів міжнародної системи даної історичної епохи (Koppel, Kisilova, 2009, p. 13).

Узагальнюючи значну кількість досліджень з теми обгрунтування явища «світового порядку», варто виокремити ключові його характеристики:

1. Легітимність. Вона не просто задає правила міжнародних відносин як i чого дозволено прагнути, як встановлювати i змінювати правила, а й показує, наскільки 3 цими правилами й принципами погоджуються дійові особи, наділені реальною владою.

2. Механізм внесення змін. Тобто, існування визнаного процесу й процедури формулювання, зміни та імплементації нових принципів і правил для усіх міжнародних акторів.

3. Баланс сил, або наявність фізичної можливості захищатися від агресії.

Р. Хаас визначає міжнародний порядок як комплекс зусиль різних держав, спрямованих на те, щоб не допускати використання військової сили задля досягнення зовнішньополітичних цілей (Haass, 2019, с. 47).

Таке розуміння світового порядку доводить домінування у сприйнятті діяльності різних країн права на власний суверенітет. Тобто, ніхто не має права тлумачити інший країні (ії лідерам, еліті), яким чином реалізовувати свої національні інтереси щодо впровадження внутрішньої та зовнішньої політики.

Його концепція «Світового порядку 1.0» грунтувалася на «підтримці та утвердженні найкращих рис суверенного порядку; зокрема, міжнародна спільнота має визнавати за державою розумну дозу автономії, утверджувати чітку повагу до кордонів і принципів міжнародного співжиття, що їх не дозволено змінювати за допомогою військової сили та інших форм примусу» (Haass, 2019, p. 266). Разом із тим, Р. Хаас визнає, що дане сприйняття стабільності світу надто застаріле. До того ж це правило порушувалося основними геополітичними гравцями світу: США, Росією, Китаєм.

Поряд із визначальною роллю суверенітету, що робило держави самостійними учасниками міжнародних відносин, гарантувалося й право «на рівних» взаємодіяти з будь-яким іншим учасником, тобто, мати рівні права в доступі до загальнолюдський ресурсів, універсальних норм, справедливих та чесних правил. Відповідно, для періоду двоблокового протистояння цього було достатньо й навіть вважалося суттєвим прогресом в забезпеченні стабільного розвитку людства. 
Саме тому світопорядок XXI ст. абсолютно $\epsilon$ крихким, розхитаним, без відчуття опори.

Г. Кіссінджер у своїй доповненій праці «Світовий порядок. Роздуми про характер націй в історичному контексті» (2014), також підтримує ідею, що сформований після Другої світової війни баланс сил та визначені критерії й правила збереження миру у світовому масштабі вичерпали себе.

Він пише: «загроза хаосу співіснує з безпрецедентною взаємозалежністю: ідеться про поширення зброї масового знищення, розпад держав, наслідки хижацького ставлення до навколишнього середовища, не викорінені практики геноциду, а також поширення нових технологій, що загрожують вивести конфлікти за межі людського контролю чи розуміння» (Kissinger, 2017, p. 8).

Відповідно, можна погодитися з авторами, що «новий світовий порядок» мусить враховувати сучасні реалії взаємозалежності, які визначають майбутнє мирне співжиття націй, - це баланс між свободою дій національних суб'єктів та міжнародним правом (принципами й правилами поведінки); баланс між легітимністю і силою; баланс між «регіональним порядком» та «міжнародним».

Для подолання хаосу світового масштабу важливо усвідомити:

1. Загрози від руйнування старого устрою й відсутності нового прямо чи опосередковано чинять тиск на абсолютно усіх міжнародних акторів;

2. конфлікти, кризи, нестабільність або безлади безпосередньо впливають на усіх учасників регіональної політики, а в подальшому залучають й світових гравців до ескалації або вирішення проблемної ситуації, що доводить взаємозалежність світу;

3. глобалізація породжує з одного боку всеосяжну взаємозалежність держав, інколи нівелюючи їхню роль міжнародними урядовими й неурядовими організаціями, які отримали частину суверенітету цих країн, а з іншого - посилила регіоналізацію та тенденцію до ізоляціонізму;

4. великі світові гравці повинні подолати зверхнє домінування над меншими і слабшими учасниками міжнародних відносин, а США мають суттєво переглянути свою стратегію домінування, адже самостійно ні забезпечити силовий баланс, ні дотримання уже сформованих Вестфальською системою правил, не здатні;

5. крім національних акторів, у сучасній системі міжнародних відносин функціонують й інші суб’єкти (МО, ТНК, ЗМІ, індивіди, терористичні організації релігійні рухи, наркокартелі тощо), які часто відіграють на багато серйознішу роль у вироблені правил, ніж деякі держави світу, саме тому їх місце, значення і роль, мають враховуватися;

6. формування «нового світового порядку» можливе за спільної згоди акторів до вироблення загальноприйнятих правил взаємодії, поведінки, які 
отримають реальні гарантії та набір усвідомлено визнаних усіма гравцями санкцій за їх порушення.

Відповідно, враховуючи характеристики світоустрою сер. XX ст., який все ще продовжує діяти, але щоденно зазнає суттєвих змін через неврахування нових глобальних та локальних тенденцій, варто розглянути основні підходи вчених щодо формування «нового світового порядку», який очікує світ протягом наступних десятиліть.

Як стверджує М. Наїм, західний (часто американський) світ розглядає дискусії щодо вироблення нового світового порядку на становлення багатополярності та рівновіддаленості як спробу похитнути могутність США, керуючись логікою «ліфта» (Naim, 2018, p. 395). Американські теоретики доводять, що країни розвиваються, рухаючись то вверх, то вниз, тому втрата всезагального контролю над світовими процесами $є$ тимчасовим явищем і США от-от повернуться до глобального домінування.

Ч. Купчан стверджує, що «західний порядок не зміниться новою політичною силою чи домінантною політичною моделлю. Це буде нічий світ. Уперше в історії світ стане взаємозалежним, але без центру тяжіння чи глобального правителя» (Kupchan, 2012).

Для Г. Кіссінджера «Світовий порядок держав, які стверджують гідність особи, учасницьке врядування та співпрацю на міжнародному рівні відповідно до узгоджених правил, може бути нашою надією та натхненням. Але прогрес на цьому шляху необхідно підтримувати низкою проміжних етапів» (Kissinger, 2017, р. 297). Відповідно визначальним трендом має залишитися процес пошуку компромісу між великими гравцями, які в подальшому здатні змусити менші країни й недержавні утворення до вироблення й дотримання правил співжиття за нової міжнародної реальності.

Р. Хаас пропонує власну концепцію «нового світового порядку», називаючи ïi «Світопорядок 2.0», до якого міжнародна спільнота рухається надзвичайно динамічними темпами. В основі цього «порядку» критика застосування силових методів (прямих і гібридних) та агресії, що занурює світ в небезпеку й нестабільність. Суверенітет, який є абсолютом, був зруйнований доктриною «обов'язку захищати», особливо щодо урядів, які свідомо порушують права власних громадян. Хоча й дана доктрина не показала своєї ефективності у застосуванні, про що свідчать затяжні конфлікти, де застосовувалися різноманітні міжнародні інтервенції.

«Світопорядок 2.0» грунтується на принципі «суверенних зобов'язань»це зобов'язання держави перед іншими державами і через них - перед громадянами інших держав (Haass, 2019, p. 261). Враховуючи, що глобалізація зробила усіх взаємозалежними, то й відповідальність за свою внутрішню й зовнішню політику держави несуть не лише перед своїми громадянами, а й перед 
сусідніми державами, регіоном місцерозташування та світовою спільнотою. Як доказ, варто згадати економічні кризи, торгівельні війни, епідемії, військові конфлікти, наслідки яких стають надто відчутними чи то у вигляді впливу на зростання економіки, чи то масових біженців, чи то невчасного контролю поширення захворювань тощо.

Ціль: щоб держави світу взяли на себе суверенні зобов'язання вести найефективнішу політику; дискваліфікація або покарання (осуд, низькі оцінки в міжнародних рейтингах) для держав, які не спроможні або не бажають здійснювати певні практики і досягати певних цілей; прагматизм й багатостороння співпраця у вирішенні надскладних завдань; знайти простір для осмисленої участі від повідних недержавних гравців (Haass, 2019, p. 290-291).

Однак, Р. Хаас доводить необхідність зберегти окремі елементи старої системи: повага до державних кордонів; механізм покарання (фізичний чи фінансовий) за його порушення; індивідуальний підхід до локальних проблем; право лише гуманітарних інтервенцій; консенсус про неприпустимість тероризму; легітимізація превентивних дій щодо недопущення поширення ядерної зброї; кібербезпека за єдиними правилами тощо.

Відповідно, автор намагається зберегти окремі елементи старої системи, яка носить ознаки обгрунтованого й доречного використання в порядку забезпечення стабільності й розвитку світу, поряд з цим визначаючи ключові загрози й виклики глобалізованого світу, які можна подолати лише новими вимогами до держав.

Учений Кай Фу Лі навпаки вважає, що держави як національні утворення в майбутньому зникнуть під тиском дій транснаціональних корпорацій, які просувають різноманітні типи продукції, побудовані на штучному інтелекті (Kai-Fu, 2020). Це має змінити не лише природу виробництва, де людина буде звільнена від виробничої й рутинної праці, а й характер взаємодій між державами, адже розвиток інновацій нівелюватиме застосування високотехнологічної зброї, що зменшуватиме кількість конфліктів та війн. Загалом, державам варто прагнути бути більш «пристосованими» до нових реалій, вести конкурентну боротьбу за швидке освоєння штучного інтелекту на користь національних інтересів і більш тісній та якісній співпраці з новими гравцями цього ринку. Саме цей елемент стане основою нового світового ладу й забезпечить відповідний баланс і стабільність.

\section{Висновки}

Отже, «новий світовий порядок», якого б зразка він не був, однозначно рухається до багатополярності. Залишаються важелі, які постійно стримують великі держави світу від нападу один на одного, але уже не залишилося аргументів, щоб забезпечувати суверенітет національних держав від більш сильних учасників. Право сильного повертається в міжнародну реальність. 
Щоденно розмивається роль міжнародного права та забезпечення прав і свобод громадян. Третя хвиля демократизації й «кінець історії» не відбувся. Демократія не стала панацеєю для людства й не відіграла роль універсального політичного порядку, що гарантує прогрес країнам. Нації та спільноти вимагають змін принципів і правил щодо гарантій їхньої свободи дій, віросповідання, комунікування, реакції на події та процеси локального й регіонального масштабів.

Консенсус щодо легітимності - це єдине правило, яке дозволить країнам виробити спільні дії побудови «нового світового порядку» у XXI ст., інакше ми усі приречені на боротьбу за виживання без навіть уявної міжнародної підтримки.

Подальші дослідження теми будуть грунтуватися на виявлені ефективних елементів геостратегії для України, враховуючи особливості розвитку міжнародних відносин у «новому світовому порядку».

\section{References:}

1. Friedman, T. (2008). Svit plaskyi! Hlobalizovanyi svit u XXI stolitti [The world is flat! The globalized world in the XXI century]. Translated from English by M. Rudenko. Kyiv: Akta.

2. Haass, R. (2019). Rozkhytanyi svit. Zovnishnia polityka Ameryky i kryza staroho ladu [A World in Disarray. American Foreign Policy and the Crisis of the Old Order]. Translated from English by M. Klymchuk. Kyiv: Osnovy.

3. Horbulin, V. (2017) 'Yakyi feniks narodytsia zi zharyshcha svitovoi hibrydnoi viiny?' [Which Phoenix will be born from the heat of World Hybrid War?] Dzerkalo tyzhnia [The Mirror of the week], [online] Available at: https://zn.ua/ukr/internal/yakiy-feniks-naroditsya-zi-zgarischa-svitovoyi-gibridnoyiviyni-259112_.html.

4. Horbulin, V. (Ed). (2017). Svitova hibrydna viina: ukrainskyi front [The World Hybrid War. Ukrainian Forefront]. Kyiv. Folio.

5. Kai-Fu, L. (2020). Sverkhderzhavy iskusstvennogo intellekta. Kitai, Kremnievaya dolina i novyi mirovoi poryadok [AI Superpowers: China, SiliconValley, and the New World Order]. Translated from English by V. Punko. Kyiv: Book Chef.

6. Kissinger, H. (2017). Svitovyi poriadok. Rozdumy pro kharakter natsii $v$ istorychnomu konteksti [World Order: Reflections on the Characters of Nations and the Course of History]. Translated from English by N. Koval. Kyiv: Nash Format.

7. Koppel, O., Kisilova, Z. (2009). 'Novyi mizhnarodnyi poriadok: strukturni kharakterystyky ta osoblyvosti formuvannia' [New international order: structural characteristics and features of formation]. Aktualni problemy mizhnarodnykh vidnosyn [Actual problems of international relations], no. 87, pp. 11-17.

8. Kupchan. Ch. (2012). No One's World: The West, the Rising Rest, and the Coming Global Turns. Oxford University Press. 
9. Naim. M. (2018). Zanepad vlady [The End of the Power]. Translated from English by O. Demianchuk. Kyiv: Book Chef.

10. Toffler, A. (2003). Metamorfozy vlasti. Znanie, bogatstvo i sila na poroge XXI veka [Powershift: Knowledge, Wealth, and Violence at the Edge of the 21st Century]. Translated from English by N. Burdukova. Kyiv: Akta.

11. World Humanitarian Data and Trends. (2017), [online]. Avialiable at: https://interactive.unocha.org/publication/datatrends2017/.

(C) Міщенко А. Б., 2020 